\title{
Comparison of the Activities of Three LdMNPV Isolates in the Laboratory Against the Chinese Strain of Asian Gypsy Moth
}

\author{
Duan L.Q. ${ }^{1}$, Otvos I.S. ${ }^{2, \#}$, Xu L.B. ${ }^{1}$, Conder N. ${ }^{*}, 2$ and Wang Y. ${ }^{1}$ \\ ${ }^{1}$ Agricultural College of Inner Mongolian Agricultural University, 275 Xin Jian East Road, Huhhot, 010019, P.R. China \\ ${ }^{2}$ Natural Resources Canada, Canadian Forest Service, Pacific Forestry Centre, 506 West Burnside Road, Victoria, \\ British Columbia, V8Z 1M5, Canada
}

\begin{abstract}
Three isolates of gypsy moth [Lymantria dispar (L.)] nucleopolyhedrovirus (LdMNPV), from China (LdMNPV-H), Japan (LdMNPV-J) and the registered strain from North America (LdMNPV-D), were bioassayed in the Inner Mongolia Autonomous Region, People's Republic of China, in 2004, using a modified version of the diet plug method, to determine their pathogenicity and virulence based on the dose- and time-response of second-instar larvae of the Chinese strain of the Asian gypsy moth. Results showed that LdMNPV-H and LdMNPV-D did not differ significantly in dose-response. The $\mathrm{LD}_{50}$ and $\mathrm{LD}_{95}$ for LdMNPV-H were 211 and 1414 OBs larva ${ }^{-1}$, respectively, while LdMNPV-D had a somewhat lower $\operatorname{LD}_{50}\left(194 \mathrm{OBs}_{\text {larva }}{ }^{-1}\right)$ and a higher $\mathrm{LD}_{95}\left(1705 \mathrm{OBs}_{\text {larva }}{ }^{-1}\right)$. LdMNPV-J was the least pathogenic, with a $\mathrm{LD}_{50}$ of 940 OBs larva ${ }^{-1}$ and $\mathrm{LD}_{95}$ of $11457 \mathrm{OBs}_{\text {larva }}{ }^{-1}$. Overall, LdMNPV-H and LdMNPV-D had similar pathogenicity against second-instar larvae of the Chinese strain of the Asian gypsy moth, and were considerably more pathogenic than LdMNPV-J. Time-responses were not significantly different among the three virus strains.
\end{abstract}

Keywords: Baculovirus, isolates, pathogenicity, virulence, Lymantria dispar.

\section{INTRODUCTION}

The gypsy moth, Lymantria dispar (L.) (Lepidoptera: Lymantriidae), is a polyphagous defoliator of Eurasian origin known to feed on over 300 species of trees and shrubs. Oaks (Quercus spp.) are the favoured hosts [1]. Two strains of gypsy moth are commonly recognized in the literature, the European strain, originating from Europe (including European Russia) and North Africa, and the Asian strain from central and eastern Asia [2].

The European strain of the gypsy moth (EGM) was brought to North America in 1869 in an attempt to improve silk production. However, a few specimens accidentally escaped during a storm and became established in the northeastern United States (US) [3]. The spread of the EGM in the US is well-documented, and this strain now occurs throughout the north-eastern US [4, 5]. EGM has also spread into Canada and is now found from Nova Scotia to midwestern Ontario, causing light to severe defoliation over large areas in Ontario and Quebec [6].

Several methods and various control agents have been used in the US, first to control it, then to slow down the spread of the gypsy moth $[4,7,8]$. During its periodic outbreaks, widespread defoliation (an average of 1.2 million ha annually) occurs when control measures are not applied [9]. It is estimated that approximately $\$ 11$ million (US) is spent annually in the US on gypsy moth control [10].

*Address correspondence to this author at the Natural Resources Canada, Canadian Forest Service, 506 West Burnside Road, Canada; Tel: 1-250-3630634; Fax: 1-250-363-0775; E-mail: nconder@nrcan.gc.ca

"Retired

(C)2010 Her Majesty the Queen in right of Canada, Natural Resources Canada, Canadian Forest Services
Recently, a revised nomenclature for gypsy moths was proposed based on wing pattern and the ability of the female to fly [2]. According to the proposed nomenclature, the subgenus Porthetria includes several closely related Lymantria spp. The common name "gypsy moth", L. dispar dispar (L.), now denotes only the winged but flightless EGM and the nearly wingless gypsy moth occurring in India, while the term "Asian gypsy moth", L. dispar asiatica Vnukovskij (AGM), refers to the strain that has winged females capable of flight. L.d. asiatica is found in Russia east of the Ural Mountains, the northern two-thirds of China, and Korea. In addition, four species of gypsy moth in the subgenus Porthetria, L. albescens Hori and Umeno, L. postalba Inoue, L. umbrosa (Butler), and L. xylina Swinhoe, and one subspecies, L.d. japonica (Motschulsky), occur in Japan. All of the females of gypsy moths occurring in the Japanese archipelago and nearby islands have functional wings. Of these, the Japanese gypsy moth, L.d. japonica, has the widest distribution throughout the Japanese mainland.

As a result of increased global commerce, repeated accidental introductions of the exotic Asian strain have occurred in North America, but so far all of these introducetions (mostly from Siberia and possibly also from China) have been successfully eradicated $[8,11]$. The AGM poses a more serious threat than the EGM for three reasons: the adult females of the Asian subspecies can fly, unlike the winged but flightless European females; the larvae of the Asian subspecies also feed on conifers [12]; and the Asian subspecies is one of the most widespread defoliators of deciduous and larch forests in China, where it periodically reaches outbreak levels [13]. In addition, AGM and EGM can hybridize, and many of the resulting females can also fly $[14,15]$. The ability of both hybrid and purebred females to fly will likely allow the AGM to spread throughout North 
America much more rapidly than the European strain has so far, and cause more devastating economic losses [16]. Thus, the introduction of the Asian subspecies presents a far greater threat to the coniferous forests of Canada and the US than that posed by its European relative.

The gypsy moth has several naturally occurring infectious diseases, one of which, is a type of baculovirus known as a multi-capsid nucleopolyhedrovirus (LdMNPV). It is a major factor controlling $L$. dispar populations in North America [17]. LdMNPV has been observed to reach epizootic proportions as larval densities increase [18]. During the latter half of the last century, research on NPV in several countries culminated in the commercial development of baculovirus insecticides for control of gypsy moth in the US, Canada and the former Soviet Union.

With the increase in international trade, it is possible that the AGM will likely become established. Russia, China, South Korea and Japan are four likely sources for these introductions because of increasing trade between Asia and North America. To prepare for the eventual potential establishment of the AGM in North America, three geographic isolates of LdMNPV were tested against laboratory colonies of the EGM and the AGM strain from Siberia, Russia (AGM-R) [16]. Restriction enzyme digestion profiles indicated that these three virus strains were similar yet distinct, and the isolates can be easily distinguished [16]. One of the three virus strains was isolated from the AGM from Heilongjiang (LdMNPV-H) Province, P.R. China. The second field-collected strain tested (LdMNPV-J) was probably obtained from L.d. japonica, the most widely distributed gypsy moth in Japan. The third strain tested was the LdMNPV used in Disparvirus ${ }^{\circledR}$ (LdMNPV-D), a baculovirus product registered for gypsy moth control in Canada [19]. This is the same strain as the one registered in the US under the trade name Gypchek [20].

Ideally, it would have been best to simultaneously bioassay all three virus strains with the three insect strains (EGM, AGM-R and AGM-C) at the same time in the same laboratory. However, quarantine requirements, as well as lack of finances and manpower, forced us to do this comparison in two stages. In the first stage, the three virus strains (D, H and J) were tested in Canada in 2001 and 2002 against EGM and AGM-R, respectively. In the second stage, the same three virus strains were tested against the AGM from China using the same laboratory rearing conditions. This second set of bioassays was done in the Inner Mongolia Autonomous Region, People's Republic of China, where the insect is native.

In this paper, we report on the results of the second stage of the investigation. We compare the pathogenicity and virulence of the same three geographic isolates of LdMNPV against the Chinese strain of the Asian gypsy moth (AGMC) in the laboratory in Huhhot, Inner Mongolia Autonomous Region, People's Republic of China in 2004.

\section{MATERIALS AND METHODOLOGY}

\section{Test Larvae}

Egg masses of AGM were collected in March, 2004, from the main host tree, Prince Rupprecht's larch, Larix principis-rupprechtii Mayr, in He-Lin County, Inner
Mongolia Autonomous Region $(150 \mathrm{~km}$ south of Huhhot, P.R. China) and stored at $5^{\circ} \mathrm{C}$ for 2 months.

Starting May 1, eggs were gently separated from the egg masses by hand. Surface decontamination was performed by wrapping the eggs (approximately 500 eggs per package) in a single layer of cheesecloth and immersing them in a $0.05 \%$ sodium hypochlorite solution for 30 seconds, followed by rinsing in five distilled water rinses for $1 \mathrm{~min}$ each. The eggs were then placed on filter paper to air-dry at room temperature. Approximately 500 eggs were placed into each of 30 fluted containers [6 oz. $(177 \mathrm{ml})$ OZ6-XE6] and covered with cardboard lids (DS306) (Sweetheart Cup Co., Owing Mills, Maryland). The eggs were reared at $25^{\circ} \mathrm{C}, 60 \% \mathrm{RH}$, and $16 \mathrm{~L}: 8 \mathrm{D}$ photoperiod, i.e. the same conditions used in the first stage in Canada [16]. After hatching, 100 larvae were transferred to each of 150 cups (described above) containing a modified artificial gypsy moth diet $[21,22]$ and reared at $25^{\circ} \mathrm{C}, 60 \% \mathrm{RH}$, and 16L:8D photoperiod. Newly moulted (less than $24 \mathrm{~h}$ old) second-instar larvae were starved for 18$24 \mathrm{~h}$ before being inoculated with a virus-contaminated diet plug.

\section{Virus Inoculum}

The activity of three geographic isolates of gypsy moth virus was tested in bioassays in the laboratory. One isolate, LdMNPV-D (Disparvirus ${ }^{\circledR}$ ), was produced and supplied by Dr. John C. Cunningham, Natural Resources Canada, Canadian Forest Service (CFS), Great Lakes Forestry Centre, Sault Ste. Marie, Ontario, Canada, from the registered virus product, Disparvirus ${ }^{\circledR}$ (Pest Management Regulatory Agency, Health Canada, Registration number 24869). The other two virus isolates were originally collected from field populations of gypsy moths. One of these two isolates, LdMNPV-H, was collected in Heilongjiang Province of China near Harbin (courtesy of Professor Yue Shukui, Northeastern Forestry University, Harbin). The other isolate, LdMNPV-J, was collected in Japan (Ibaraki Prefecture, Honshu Island; courtesy of Dr. Shimazu Mitsuaki, Forestry and Forest Products Research Institute) [16].

All three LdMNPV strains were amplified twice in vivo and mass-produced under quarantine conditions at the Pacific Forestry Center (PFC), Natural Resources Canada, Canadian Forest Service, using freshly moulted fourth instar AGM-R larvae. The laboratory colony of AGM-R used for the amplification and mass-production were obtained from the Otis Methods Development Center, USDA, APHIS, PPQ, Massachusetts (courtesy of Dr. Vic Mastro and Mr. John Tanner). The mass-produced virus was stored for 2 years in insect cadavers in $50 \mathrm{ml}$ centrifuge tubes at $-20^{\circ} \mathrm{C}$. The insect cadavers were shipped to China for processing in early 2003, among freezer packs in a Styrofoam cooler. Virus occlusion bodies (OBs) were purified following the procedure described previously [16]. The stock suspension of OBs for each LdMNPV strain was prepared 1 month before the bioassays were conducted, and stored at $4{ }^{\circ} \mathrm{C}$ until use. OBs were quantified using a haemocytometer.

\section{Dose-Response}

Freshly moulted second-instar AGM-C (L.d. asiatica) larvae were starved for $24 \mathrm{~h}$ and then inoculated with $1 \mu \mathrm{l}$ of 
virus suspension of one of the three strains of LdMNPV using a modified version of the contaminated diet-plug method $[23,24]$ to determine the dose and time-response to each LdMNPV isolate. Control larvae were fed a diet plug inoculated with distilled water $\left(\mathrm{dH}_{2} \mathrm{O}\right)$. Virus inoculations targeted 5, 30, 50, 80, 85, 90 and 95\% mortality (determined by preliminary bioassays), thereby giving the narrowest confidence limits for both the $\mathrm{LD}_{50}$ and $\mathrm{LD}_{95}$ [25]

During the preliminary bioassays of all three LdMNPV strains, a concentration close to the $\mathrm{LD}_{50}$ for LdMNPV-D was determined. However, the results of the Probit analysis for the other two virus strains either did not fit the Probit curve or the replicates differed substantially from each other, so an analysis of the pooled data could not be performed and no doses approximating the $\mathrm{LD}_{50} \mathrm{~s}$ could be determined for either LdMNPV-H or LdMNPV-J in 2003. Because of the possibility that the outbreak would collapse (depriving us of a source of larvae for the bioassay) and monetary constraints, it was decided not to repeat this preliminary bioassay, but instead to add two extra doses to improve the chances of calculating the $\mathrm{LD}_{50}$ and $\mathrm{LD}_{95}$ dose for LdMNPV-H or LdMNPV-J. Therefore, for the full bioassay, for LdMNPV$\mathrm{D}$, five concentrations were used to determine the $\mathrm{LD}_{50}$, while for LdMNPV-H and LdMNPV-J two extra doses were used (total of seven concentrations) to determine the $\mathrm{LD}_{50}$ and $\mathrm{LD}_{95}$ in 2004.

The starved larvae were reared in darkness at $25 \pm 1{ }^{\circ} \mathrm{C}$, $60 \% \mathrm{RH}$ and allowed to feed for $24 \mathrm{~h}$ on the treated diet. Larvae from laboratory colonies are used to eating this artificial (substitute) diet and readily accept this diet. After $24 \mathrm{~h}$, larvae that had consumed the entire plugs were transferred individually to Solo PL1 plastic souffles $(29.6 \mathrm{ml}$ cups, Solo Cup Company, Urbana, IL), containing untreated fresh diet and capped with Solo PL1 paper lids, and reared at $25 \pm 1{ }^{\circ} \mathrm{C}, 60 \% \mathrm{RH}$, and $16 \mathrm{~L}: 8 \mathrm{D}$ photoperiod. Larvae that did not consume the entire plug were discarded. Bioassay of each viral strain dose and a corresponding experimental control group was replicated three times with 72 larvae per replicate, for a total of 216 larvae per concentration, for each viral isolate. Food was changed weekly and the larvae were monitored daily for mortality. Moribund larvae were considered as dead and gently prodded with a probe. Mortality caused by virus was diagnosed from typical virus disease characteristics (soft, flaccid body) and confirmed by microscopic examination. Larval mortality was analyzed using Probit analysis [26] to estimate the $\mathrm{LD}_{50}, \mathrm{LD}_{95}$, and $95 \%$ confidence limits.

\section{Time-Response}

Second-instar AGM-C larvae were treated using virusinoculated diet plugs and then reared on non-contaminated diet. The virus doses were standardized to produce similar mortality rates in order to facilitate comparisons among the three virus strains. Equally effective doses causing less than $50 \%$ mortality were chosen, because the $\mathrm{ST}_{50} \mathrm{~s}$ generated from these data are relatively insensitive to dose differences [27]. Data obtained from the dose-response bioassays for each viral isolate were analyzed to determine $\mathrm{ST}_{50}$ using ViStat [28].

\section{RESULTS}

\section{Dose-Response}

There were no significant differences in dose-response $\left(\mathrm{LD}_{50}\right.$ and $\left.\mathrm{LD}_{95}\right)$ among the three replicates for each of the three LdMNPV strains, as determined by overlapping $95 \%$ confidence intervals [26]. Therefore, the three replicates for each virus strain were pooled and the combined data were used for the Probit analysis of the viral strains' doseresponse. Mortality in the control groups was very low (2.8\%). Natural response was estimated [26] for the regression of data sets in which control mortality occurred. The experiment was terminated $21 \mathrm{~d}$ post-inoculation, and no pupation occurred within this observation period.

The dose-response bioassays of larvae of AGM-C showed that LdMNPV-H and LdMNPV-D had very similar activity against the second-instar AGM-C larvae. The median lethal doses $\left(\mathrm{LD}_{50}\right)$ for LdMNPV-D and LdMNPV-H were 194 and 211 OBs larva $^{-1}$, respectively, and were not significantly different (i.e. there was overlap of $95 \%$ confidence limits of $\mathrm{LD}_{50}$ ). Similarly, $\mathrm{LD}_{95} \mathrm{~s}$ were not significantly different at 1705 and $1414 \mathrm{OBs}_{\text {larva }}{ }^{-1}$, respectively. LdMNPV-J was significantly less pathogenic against the AGM-C (the 95\% confidence limits did not overlap), having the highest $\mathrm{LD}_{50}$ and $\mathrm{LD}_{95}$ (940 and 11457 OBs larva ${ }^{-1}$, respectively) (Table $\mathbf{1}$ ).

The slope of the regression line in Probit analysis has generally been interpreted as a measure of variability in host susceptibility to the virus [29], with less variation among hosts producing steeper slopes. Slopes of the dose responses for the three isolates (Table 1) indicate that AGM-C is equally susceptible to LdMNPV-H and LdMNPV-D and least susceptible to the infection by LdMNPV-J. Both LdMNPV-H and LdMNPV-D isolates caused higher mortality of AGM-C larvae infected in the second instar, than LdMNPV-J isolate. Regression lines for the doseresponse of AGM-C larvae to the three virus strains were parallel, and the ratio of relative potency of LdMNPV-H and LdMNPV-D to LdMNPV-J was estimated $[25,26]$ to be 4.5 and 4.8 fold, respectively.

\section{Time-Response}

Virulence, best determined by the time-response, is the length of time it takes for the virus to cause mortality and is an important measure of the effectiveness of the virus as a biopesticide [27]. The virulence of the three LdMNPV strains to second-instar AGM-C larvae was compared in terms of median time response, $\mathrm{ST}_{50}$ (time required to kill $50 \%$ of the larvae), at the equally effective dose. There were no significant differences in the time-response $\left(\mathrm{ST}_{50}\right)$ among the replicates (receiving doses causing somewhat less than $50 \%$ mortality) within each of the three virus strains bioassayed. Therefore, data sets were pooled for each of the virus strains prior to analysis with ViStat [28].

The time-response data indicated that all three strains of the LdMNPV have similar $\mathrm{ST}_{50} \mathrm{~S}$, as determined by the overlapping 95\% confidence limits. LdMNPV-D, LdMNPV$\mathrm{H}$ and LdMNPV-J had $\mathrm{ST}_{50} \mathrm{~S}$ of $8.9,8.3$ and $8.6 \mathrm{~d}$, respectively. However, for two of the three virus strains tested (LdMNPV-H and LdMNPV-J), the observed $\chi^{2}$ values were 
Table 1. Response of Second-Instar Larvae of the Chinese Strain of Lymantria dispar asiatica to Three Geographic Isolates (LdMNPV-D, LdMNPV-H, and LdMNPV-J) of Nucleopolyhedrovirus in Laboratory Bioassay, Huhhot, P.R. China, 2004

\begin{tabular}{|c|c|c|c|c|c|c|c|}
\hline \multirow{2}{*}{ Isolate } & \multicolumn{4}{|c|}{ Dose Response } & \multicolumn{3}{|c|}{ Time Response } \\
\hline & $\operatorname{LD}_{50}{ }^{a}\left(O B s\right.$ larva $\left.^{-1}\right)$ & $\mathrm{LD}_{95}{ }^{\mathrm{a}}\left(\mathrm{OBs}\right.$ larva $\left.^{-1}\right)$ & Slope $\pm \mathbf{S E}$ & $\chi^{2} / \mathbf{d f} \mathbf{f}^{b}$ & $\mathrm{ST}_{50}{ }^{\mathrm{c}}$ (day) & Slope \pm SE & $\chi^{2} / \mathbf{d} \mathbf{f}^{\mathrm{d}}$ \\
\hline$L d M N P V$-D & $194(157-235)$ & $1705(1254-2541)$ & $1.74 \pm 0.14$ & $12.72 / 13$ & $8.85(8.45-9.25)$ & $10.31 \pm 1.17$ & $9.54 / 9$ \\
\hline$L d M N P V-\mathrm{J}$ & $940(748-1167)$ & $11457(7768-19366)$ & $1.51 \pm 0.13$ & $6.17 / 10$ & $8.61(8.19-9.03)$ & $8.18 \pm 0.80$ & $23.88 / 12$ \\
\hline
\end{tabular}

${ }^{\text {a }}$ calculated using Polo PC [26]; numbers in parentheses indicate $95 \%$ confidence limits.

${ }^{b}$ the degrees of freedom are less than 14 and differ among the analyses because data points considered "outliers" (dose responses that were abnormally high or low) were excluded from the final determination of the LDs for each virus.

${ }^{c}$ determined using pooled replicates causing less than 50\% mortality; calculated using ViStat [28]; numbers in parentheses indicate $95 \%$ confidence limits and were calculated as twice the standard error of the $\mathrm{ST}_{50}$.

${ }^{d}$ degrees of freedom differ because of the number of days that virus-induced mortality occurred varied among the three LdMNPV strains.

higher than the predicted $\chi^{2}$ values (Table 1), indicating a greater deviation of the response data from the regression lines, i.e. the experimental data for these two strains were a poor fit for the model used by ViStat [16].

\section{DISCUSSION}

Making direct comparisons between the results obtained in this paper and those reported in previous studies is somewhat problematic, because the bioassay methodologies used vary considerably. Unlike many other studies of gypsy moth virus strains, in which the lethal concentrations (LC) for different isolates of LdMNPV were determined, this current and one of the previous studies [16] determined the more accurate lethal doses (LD) of three isolates of LdMNPV. Interpreting the results of some of the earlier studies using LC is made even more difficult because, in some cases, cytoplasmic viruses were also tested at the same time $[30,31]$. Earlier studies also reported variations in the biological activities of different geographic isolates of gypsy moth virus [30-35], and variation in the responses of gypsy moth larvae from different geographic locations to the same virus strain. The age or phase of the gypsy moth outbreak, the isolation, preparation and storage of the strains are also thought to influence the biological activity (both pathogenicity and virulence) of the virus [33].

A previous study [16], using the contaminated diet plug method, compared the dose and time-responses of secondinstar larvae of the EGM and AGM-R to three gypsy moth virus isolates. Both experiments used almost identical methodologies, the only difference being that the fieldcollected larvae used for the bioassay in China were starved for $24 \mathrm{~h}$ prior to inoculation, whereas the larvae used in the Canadian study were from laboratory colonies and were not starved. Because we tested the same three virus strains against second-instar AGM-C larvae using an almost identical methodology, most of the comparisons will be between the results we report in this paper and the previous study. Hence, we presented our data using the same format (Table 1) as in Ebling et al. [16] to facilitate comparison of the bioassay results.

\section{Comparison of the Pathogenicity of Three LdMNPV Isolates Against AGM-C and AGM-R}

When second instar AGM-C larvae were challenged with the three virus isolates, we found that the pathogenicity of
LdMNPV-D and LdMNPV-H against AGM-C was not significantly different. However, both LdMNPV-D and LdMNPV-H were significantly more pathogenic against AGM-C than LdMNPV-J.

In comparison, Ebling et al. [16] reported that LdMNPV$\mathrm{H}$ was more pathogenic against AGM-R than LdMNPV-J, and significantly more pathogenic than LdMNPV-D. LdMNPV-H had a significantly lower LD $_{50}(648$ OBs larva $^{-1}$ ) than LdMNPV-J (1260 OBs larva $\left.{ }^{-1}\right)$ and LdMNPV-D (1904 OBs larva ${ }^{-1}$ ). The LD 95 of LdMNPV-H (8540 OBs larva $^{-1}$ ) was significantly lower than that of LdMNPV-D (208 $600 \mathrm{OBs}_{\text {larva }}{ }^{-1}$ ), but not for LdMNPV-J (20 $841 \mathrm{OBs}$ $\left.\operatorname{larva}^{-1}\right)$. Comparing the pathogenicity of the three virus isolates against AGM-C (this study) and AGM-R [16], LdMNPV-D and LdMNPV-H were significantly more pathogenic against the AGM-C than to the AGM-R, while LdMNPV-J was somewhat more pathogenic against the AGM-C than to the AGM-R, but not significantly.

\section{Comparison of the Virulence of Three LdMNPV Isolates Against AGM-C and AGM-R}

Interesting patterns emerged when we compared the time-responses (virulence) of the same three virus isolates against AGM-C and AGM-R. There were no significant differences among the median time-responses $\left(\mathrm{ST}_{50}\right)$ of the three virus isolates (LdMNPV-D, LdMNPV-H and LdMNPV-J) when second-instar AGM-C larvae were challenged (Table 1). Similarly, there were no significant differences among the three virus isolates in the time-responses when second-instar AGM-R larvae were challenged [16]. The $\mathrm{ST}_{50}$ of $\mathrm{AGM}-\mathrm{R}$ to the three virus isolates varied from 10.4 to $11.5 \mathrm{~d}$ [16]. These $\mathrm{ST}_{50}$ values are about 1.5 to $2 \mathrm{~d}$ longer than what we obtained for AGM-C, which varied from 8.3 to $8.9 \mathrm{~d}$ (Table $\mathbf{1}$ ).

\section{Possible Sources of Variability in Virus Activity}

LdMNPV-D, the active ingredient in the registered virus products in North America (Gypchek and Disparvirus ${ }^{\circledR}$ ), was significantly more pathogenic against the EGM than the two strains of AGM bioassayed. It has been postulated that this virus strain was accidentally introduced into North America, either with its host or with one of the introduced parasitoids of gypsy moth [36]. Thus, it is highly likely that LdMNPV-D virus strain has always been associated with the EGM. 
LdMNPV-H and LdMNPV-D were equally pathogenic against AGM-C, and significantly more than LdMNPV-J. The fact that LdMNPV-D and LdMNPV-H were equally effective was unexpected, because one would have expected that LdMNPV-H, isolated in Heilongjiang Province in China, to be more pathogenic to L.d. asiatica. Likewise, it was somewhat surprising that LdMNPV-J was the least pathogenic strain against AGM-C (Table 1), and only moderately pathogenic against AGM-R [16], unless it was originally isolated from a species of lymantriid other than the Japanese gypsy moth (L.d. japonica).

Previous studies (using $\mathrm{LC}_{50}$ ) have revealed differences in pathogenicity among geographic isolates of LdMNPV. One study [37] found that the LdMNPV isolate from France was less active compared with a North American and a Korean isolate. In a different study [38], six geographic isolates of LdMNPV from China were tested against EGM established in eastern North America. None of these virus strains were found to be as effective as the strain used in the currently registered products (Gypchek and Disparvirus ${ }^{\circledR}$ ) for gypsy moth control in North America. In a third study [34], 19 different strains of LdMNPV were bioassayed against a laboratory colony of the introduced EGM, including one strain from Japan. The median lethal concentration $\left(\mathrm{LC}_{50}\right)$ values of the geographical isolates against the colonized strain of $L$. dispar in the US varied from $1.7 \times 10^{3}$ to more than $5 \times 10^{6} \mathrm{OBs} \mathrm{m}^{-1}$. It was also found that the North American virus isolate was generally the most active against gypsy moths, and the virus from Japan was the least active of the isolates tested. Unfortunately, the origin of the Japanese virus strain tested was not indicated [34], and when they did their work the gypsy moth complex was less understood.

As previously mentioned, it is also possible that the nucleopolyhedrosis virus from Japan was not isolated from L.d. japonica, but from one of the other species of Lymantria that are known from Japan. Recent taxonomic work [2] proposed that what was once considered a single species $(L$. dispar) actually consists of several species and subspecies, five of which occur in the Kurile Islands, Japan, and Ryukyu Islands. Interestingly, the AGM, L.d. asiatica, was not listed as one of the gypsy moths occurring in Japan [2]. Despite repeated attempts, we could not precisely pinpoint either the location or the scientific name of the host from which the LdMNPV-J strain we used was obtained. However, we think that it is highly probable that the virus strain we used was obtained from L.d. japonica (Motschulsky), the most widely distributed subspecies of gypsy moth in Japan.

These variances may also be due to differences in larval strains of AGM used in the two studies. The AGM-R larvae tested during the previous study [16] were reared from a laboratory colony of a Russian strain obtained from the Otis Methods Development Center, USDA, APHIS, PPQ, Massachusetts, that had been in rearing for over 51 generations (John Tanner, USDA, personal communication), while the AGM-C larvae tested in our experiment were collected from the field in He Ling County near Huhhot in north-western China. Thus, the differences in the experimental results may also be due either to changes in resistance in the AGM-R somehow induced by prolonged breeding under laboratory conditions, compared with the field-collected AGM-C, or simply to comparing different strains of the same insect. It would be interesting to see if the biological activity of these same three geographic strains of virus would be different if tested (using the same methodology) against a field-collected Russian and Japanese strains of Asian gypsy moths.

It has been shown by this study and others that both the geographic isolate and the gypsy moth larval strain tested influence the effectiveness of the virus as a biopesticide. Therefore, it is very important to select the most virulent isolate for a given host population, first by laboratory bioassay, then by confirmation in small-scale field tests, before seeking registration or proceeding with large-scale field use as a biopesticide. However, this is not always practical in operational gypsy moth, or other defoliator, control programs, if the virus product is not already registered.

The AGM-R tested in the previous study [16] and the AGM-C in our current study occur in the two geographic areas from which the introduction of L.d. asiatica to North America is most likely to originate due to the ever-increasing trade with these two countries. There are two other potential sources for introduction from Asia, Japan and Korea. Given the differences in the dose and time responses observed in the AGM-R challenged in the previous study [16] and in this study (AGM-C), it would be highly desirable to test these same three gypsy moth virus strains against the Japanese gypsy moths identified as native to Japan [2], or at the very least against L.d. japonica (the most common subspecies). This subspecies, with its wide distribution in Japan, may be a third possible source of introduction of AGM into North America.

Recent DNA work on lymantriid moths [39] generally agrees with the earlier work by Pogue and Schaeffer [2], but also states that L.d. asiatica and L.d. japonica cannot always be easily separated. Increasing trade among Asian countries, with its potential for introductions could have further complicated the distinction between L.d. asiatica and L.d. japonica (LM Humble 2010, personal communication). It is recommended that the same three virus strains be bioassayed against recently collected strains of L.d. asiatica from the Russian Far East, China, and Korea, as well as L.d. japonica from Japan. DNA barcoding of the field-collected AGM strains being bioassayed would also be desirable, especially in light of possible past misidentifications of some Lymantria spp. [40]. The other, less widely distributed gypsy moths of the subgenus Porthetria in Asia, Lymantria albescens, L. postalba, L. umbrosa, and L. xylina, could be studied at a later date. Bioassaying the species or subspecies of gypsy moth occurring in Japan could be done cooperatively with researchers in Japan to avoid quarantine concerns and accelerate this research.

\section{ACKNOWLEDGEMENTS}

Thanks are extended to Mr. Te Muqin, Mr. Gang Song and Mr. Shengguo Zhao, Inner Mongolia Forestry Protection Station, for providing the Asian gypsy moth egg masses; and to Xiaoqin Wang, Lichun Zhu and Yuye Gong for their assistance bioassaying the Chinese strain of Asian gypsy moth. Funding for the bioassay and publication costs was provided by the Canadian Forest Service, Natural Resources 
Canada. Dr. Chris Lucarotti and Mr. Peter Ebling, both from the Canadian Forest Service, provided constructive comments on an earlier version of this manuscript. We would also like to thank the anonymous reviewers for their valued comments on the earlier draft of this manuscript.

\section{REFERENCES}

[1] Leonard DE. Bioecology of the gypsy moth. In: Doane CC, McManus ML Eds, The Gypsy Moth: Research Toward Integrated Pest Management. United States Department of Agriculture, Forest Service, Washington, D.C. Technic Bull 1981; 1584: pp.9-29.

[2] Pogue MG, Schaefer PW. A review of selected species of Lymantria Hübner (1819) including three new species (Lepidoptera: Noctuidae: Lymantriinae) from subtropical and temperate regions of Asia, some potentially invasive to North America. United States Department of Agriculture, Forest Service. Forest Health Technology Enterprise Team Technol Transfer, FHTET-2006-07. Washington, DC, 2007.

[3] Liebhold A, Mastro V, Schaefer PW. Learning from the legacy of Léopold Trouvelot. Bull Entomol Soc Am 1989; 35: 20-2.

[4] McManus ML, McIntyre T. Introduction: historical chronology. In: Doane CC, McManus ML, Eds. The Gypsy Moth: Research Toward Integrated Pest Management. United States Department of Agriculture, Forest Service, Washington, D.C. Technic Bull 1981; 1584: pp. 1-7.

[5] Montgomery ME, Wallner WE. The gypsy moth: a westward migrant. In: Berryman AA, Ed. Dynamics of forest insect populations: patterns, causes, implications. New York, Plenum Press, 1988; pp. 253-75.

[6] Jobin L. Gypsy moth, Lymantria dispar. In: Armstrong JA, Ives WGH Eds, Forest Insect Pests in Canada. Natural Resources Canada, Canadian Forest Service, Science and Sustainable Development Directorate, Ottawa, 1995; pp. 133-9.

[7] Sharov AA, Leonard D, Liebhold AM, Roberts EA, Dickerson W. Slow the spread: a national program to contain the gypsy moth. J For 2002; 100: 30-6.

[8] Otvos IS. Integrated pest management in forestry: Potential and challenges, In: Koul O, Dhaliwal GS, Cuperus GW, Eds. Integrated pest management: potential, constraints and Challenges. CAB International, Cambridge, MA, 2004; pp. 205-54.

[9] Reardon R, Podgwaite J, Zerillo R. Gypchek - the gypsy moth nucleopolyhedrosis virus product. United States Department of Agriculture, Forest Service, Forest Health Technology Enterprise Team, Northeastern Area State and Private Forestry. FHTET 9616. Morgantown, WV 1996.

[10] Pimentel D, Zuniga R, Morrison D. Update on the environmental and economic costs associated with alien-invasive in the United States. Ecol Econ 2005; 52: 273-88.

[11] Krcmar-nozic E, Wilson B, Arthur L. The potential impacts of exotic forest pests in North America: a synthesis of research. Information Report BC-X-387, Natural Resources Canada, Canadian Forest Service, 2000.

[12] Baranchikov YN. Biological basis of the evolution of host relationships in Eurasian gypsy moth populations. In: Wallner WE, McManus KA. Tech. Coords, Proceedings, Lymantriidae: A comparison of features of New and Old World tussock moths; 1988 June 26 -July 1, New Haven, CT. United States Department of Agriculture General Technical Report, NE-123. US Department of Agriculture, Forest Service, Northeastern Forest Experiment Station, Broomall, PA, 1989; pp. 319-38.

[13] Schaefer PW, Weseloh RM, Sun X, Wallner WE, Yan J. Gypsy moth, Lymantria (=Ocneria) dispar (L.) (Lepidoptera: Lymantriidae), in the People's Republic of China. Environ Entomol 1984; 13: 1535-41.

[14] Reineke A, Zebitz CPW. Flight ability of gypsy moth females (Lymantria dispar L.) (Lep., Lymantriidae): a behavioural feature characterizing moths from Asia? J Appl Entomol 1998; 122: 30710 .

[15] Keena MA, Wallner WE, Grinberg PS, Cardé RT. Female flight propensity and capability in Lymantria dispar (Lepidoptera: Lymantriidae) from Russia, North America, and their reciprocal $F_{1}$ hybrids. Environ Entomol 2001; 30: 380-7.
[16] Ebling PM, Otvos IS, Conder N. Comparative activity of three isolates of LdMNPV against two strains of Lymantria dispar. Can Entomol 2004; 136: 737-47.

[17] Elkinton JS, Liebhold AM. Population dynamics of gypsy moth in North America. Annu Rev Entomol 1990; 35: 571-96.

[18] Doane CC. Primary pathogens and their role in the development of an epizootic in the gypsy moth. J. Invertebr Pathol 1970; 15: 21-33.

[19] van Frankenhuyzen K, Reardon RC, Dubois NR. Forest defoliators. In: Lacey LA, Kaya HK, Eds. Field manual of techniques in invertebrate pathology: application and evaluation of pathogens for control of insects and other invertebrate pests, $2^{\text {nd }}$ ed. The Netherlands: Springer, Dordrecht, 2007; pp. 481-504.

[20] Cunningham JC, Kaupp WJ, Howse GM. Development of nuclear polyhedrosis virus for control of gypsy moth (Lepidoptera: Lymantriidae) in Ontario. I. Aerial spray trials in 1988. Can Entomol 1991; 123: 601-9.

[21] Bell RA, Owens DC, Shapiro M, Tardif JR. Development of massrearing technology. In: Doane CC, McManus ML, Eds. The Gypsy Moth: Research Toward Integrated Pest Management. United States Department of Agriculture, Forest Service, Washington, D.C. Technic Bull 1981; 1584: 599-633.

[22] Odell TM, Keena MA, Willis RB. Dietary influence of iron formulation on the development of gypsy moth (Lepidoptera: Lymantriidae) in laboratory colonies. Ann Entomol Soc Am 1997; 90: $149-54$.

[23] Kaupp WJ, Ebling PM. Response of third-, fourth-, fifth-, and sixth-instar spruce budworm, Choristoneura fumiferana (Clem.), larvae to nuclear polyhedrosis virus. Can Entomol 1990; 122: 1037-8.

[24] Li SY, Otvos IS. Differential mortality between male and female Choristoneura occidentalis (Lepidoptera: Tortricidae) larvae exposed to a baculovirus with or without optical brighteners. Can Entomol 1999; 131: 65-70.

[25] Robertson JL, Preisler HK. Pesticide bioassays with arthropods. London, UK: CRC Press 1992.

[26] LeOra Software. POLO-PC a user's guide to Probit or Logit analysis. Berkeley, CA: LeOra Software 1994.

[27] van Beek NAM, Hughes PR. Minireview: The response time of insect larvae infected with recombinant baculoviruses. J Invertebr Pathol 1998; 72: 338-47.

[28] Hughes PR, Wood HA. ViStat. Statistical package for the analysis of baculovirus bioassay data. Ithaca, NY: Boyce Thompson Institute, Cornell University 1990.

[29] Hughes PR, Wood HA, Burand JP, Grandos RR. Quantification of the dose-mortality response of Trichoplusia ni, Heliothis zea, and Spodoptera frugiperda to nuclear polyhedrosis viruses: applicability of an exponential model. J Invertebr Pathol 1984; 43: 343-50.

[30] Magnoler A. Susceptibility of gypsy moth larvae to Lymantria spp. nuclear- and cytoplasmic polyhedrosis viruses. Entomophaga 1970; 15: 407-12.

[31] Rollinson WD, Lewis JL. Susceptibility of gypsy moth larvae to Lymantria spp. nuclear and cytoplasmic polyhedrosis viruses. Plant Prot (Zašt Bilja) 1973; 24: 163-8.

[32] Rupérez A. Effectiveness of Limantria dispar L. polyhedrosis viruses of different provenience. Plant Prot (Zašt Bilja) 1973; 24: 187-91.

[33] Vasiljević L, Injac M. A study of gypsy moth viruses originating from different geographical regions. Plant Prot (Zašt Bilja) 1973; 24: $169-86$.

[34] Shapiro M, Robertson JL, Injac MG, Katagiri K, Bell RA. Comparative infectivities of gypsy moth (Lepidoptera: Lymantriidae) nucleopolyhedrosis virus isolates from North America, Europe, and Asia. J Econ Entomol 1984; 77: 153-6.

[35] Shapiro M, Robertson JL. Natural variability of three geographic isolates of gypsy moth (Lepidoptera: Lymantriidae) nuclear polyhedrosis virus. J Econ Entomol 1991; 84: 71-5.

[36] Glaser RW. Wilt of gipsy-moth caterpillars. J Agric Res 1915; 4: 101-28.

[37] Narang N, Herard F, Dougherty EM, Chen K, Vega FE. A gypsy moth (Lymantria dispar, Lepidoptera: Lymantriidae) multinucleocapsid nuclear polyhedrosis virus from France: comparison with a North American and a Korean strain. Eur J Entomol 2001; 98: 18994. 
[38] Lewis FB, Wallner WE, Rollinson WD. Activity of lymantriid NPVs from the People's Republic of China against North American Lymantria dispar. Entomophaga 1984; 29: 299-302.

[39] de Waard J, Mitchell A, Keena MA, et al. Towards a global barcode library for Lymantria (Lepidoptera: Lymantriinae) tussock moths of biosecurity concern. PloS One 2010, 5: 1-9.

[40] Humble L, de Waard J, Floyd R, Lima J, Hanner R. Additions and corrections to barcode libraries for Lymantria spp. In: McManus
KA, Gottschalk KW Eds., Proceedings, $20^{\text {th }}$ US Department of Agriculture interagency research forum on invasive species; 2009 January 13-16; Annapolis, Maryland. United States Department of Agriculture General Technical Report, NRS-P-51. US Department of Agriculture, Forest Service, Northern Research Station, Newton Square, PA, 2009; 79.

Received: October 29, 2010

(C) Duan et al.; Licensee Bentham Open.

This is an open access article licensed under the terms of the Creative Commons Attribution Non-Commercial License (http://creativecommons.org/licenses/by$\mathrm{nc} / 3.0 /$ ), which permits unrestricted, non-commercial use, distribution and reproduction in any medium, provided the work is properly cited. 